See discussions, stats, and author profiles for this publication at: https://www.researchgate.net/publication/270897079

\title{
Assessment of motorways of the sea through a method based on analysis of decision groups
}

Conference Paper · October 2014

Dol: 10.1201/b17494-12

CITATIONS

0

3 authors:

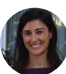

Alba Martínez López

University of A Coruña

13 PUBLICATIONS 38 CITATIONS

SEE PROFILE

(3)

Alicia Munin

University of A Coruña

8 PUBLICATIONS 10 CITATIONS

SEE PROFILE

Some of the authors of this publication are also working on these related projects:

SIGMA-N View project
READS

40

Daniel Peña

Universidad Mayor de San Andres

2 PUBLICATIONS 6 CITATIONS

SEE PROFILE 


\title{
Assessment of motorways of the sea through a method based on analysis of decision groups
}

\author{
A. Martínez-López \& D. Pena-Agras \\ Department of Naval Engineering, University of A Coruña, Ferrol, Spain. Edificio de Talleres (Campus de \\ Esteiro), C/Mendizábal, 15403, Ferrol, A Coruña. Spain \\ amartinezl@udc.es; daniel.pena1@udc.es
}

\author{
A. Munín-Doce \\ Integrated Group for Engineering Research, Ferrol, Spain. Edificio de Talleres (Campus de Esteiro), \\ C/Mendizábal, 15403, Ferrol, A Coruña. Spain \\ inaamd01@udc.es
}

\begin{abstract}
Despite the European Union have favoured maritime traffic for years, through exceptions in the application of competition rules, in recent years these exceptions have disappeared progressively. Therefore, shipping companies have to adapt their service to the real needs of the shippers, identifying the controllable characteristics in their operational framework in order to act on them. Hence, this paper focuses on the introduction of a new hybrid model in multimodal transport, which allows the opportunity assessment for a shipping company, but through the decision criteria of the service user: the shipper. The results allow the identification of the main controllable and uncontrollable variables, constraints and objective functions for the shipping company, which condition the success of the multimodal chains from the shipper's perspective. This work develops a particular case to show this hybrid model: shipping companies considering, as a business strategy, to establish a motorway of the sea in Spain.
\end{abstract}

\section{INTRODUCTION AND METHODOLOGY}

The European Union (EU) transferred the responsibility for the development of multimodal transport to private companies from the administrations (Gesé \& Baird, 2010), so shipping companies assumed the establishment of this kind of motorways. On the other hand, in recent years numerous studies, focused on the transport modal choice, were able to reflect the shipper's behaviour. However, their implementation in the classical approach to the opportunity analysis for the establishment of a motorway of the sea, integrated in a multimodal chain, has been hitherto practically inexistent from shipping companies' perspective. This paper aims to fill these gaps by offering a method of the opportunity assessment for a business strategy of a shipping company, but through the decision criteria of the service user (the shipper). Therefore, for the selection of the transport mode, we will used an explanatory hybrid model.

The evaluation of the business strategy for the establishment of a motorway of the sea can have the following stages: the analysis of the opportunity, the analysis of acceptability and finally the analysis of feasibility. The first one must provide a qualitative approach, evaluating the goodness level of its integration into the current framework and into the forecast scenarios. This qualitative evaluation allows the initial determination of the main variables, constraints and objective functions, which condition the potential success of the motorway, and therefore provide a first approach to the most suitable routes and fleets. Thus, this paper uniquely focuses on the opportunity assessment. The method proposed must be able not only to identify the main variables, but also to determine those that shipping companies can modified (controllable) and those that they cannot.

The transport sector allows high possibilities for differentiation due to its structural factors; essentially, due to this possibility, different transport modes can carry out the same service. For this reason, this work assumes that the differentiation of the transport company is the business's capacity to adapt its services to the real needs of clients (specialization focused on the shipper). Additionally, this work makes another assumption about the initial situation of the company: the business strategy (the establishment of a motorway of the sea) responds to the exploitation of a new transport service. 
The competitive advantage of a transport company rises when it offers services with more attractive characteristics in cost and differentiation in relation to another business in the sector. In order to reach and to keep that advantage, the transport company should configure its services (strategic planning), integrating the decisions made from the evaluation of three areas:

- The service scope: market needs. Quantitative and qualitative analysis (Sapag 2001).

- The company scope: competitiveness and opportunities in front of competitors.

- The geographic scope: the scenario for service and technological needs.

Although the previous points may be valid for any sector, they are not sufficient for the transport sector because countries usually consider it as strategic in their economy; therefore, Government intervention is usually very relevant to transport activity. In fact, the transport regulation is responsible for the opportunity differentiation for many companies in this sector. Hence, it is necessary to include a new area in the evaluation:

- Regulation scope: trend and influence of the legislative framework in the sector.

The results achieved from the previous analysis (as in any decision process) lead to the identification of inputs: controllable (different options for projects) and uncontrollable (Sapag 2001). This work uses the previous process to configure the strategic planning of a transport company, but evaluating every scope from the point of view of the client: the shipper. Therefore, following this method, the client is the decision maker at every moment of the company strategic analysis.

Since the 1970s, the interest in the selection of the most suitable transport system for different cases has risen, and consequently many studies focused on this issue, especially ones that propose explanatory models (Mangan et al. 2001). Thus, previous authors determined different models: input models, output models, processing models (structural and sociological model). These previous models consider the application of different decision groups for the decision maker, in order to reach their aims.

The method proposed in this paper tries to take into account the majority of the decision groups, used in the previous models, but from a different perspective, since these decision groups influence the four evaluation areas of a transport company strategy. Thus, we call the provided method hybrid model, based on the evaluation of four different scopes, in terms of the following decision groups:

- Activity requirements to assure competitiveness (ARC): cost and time are the main criteria to determine the costumer's decision about a transport system. In this group, the opportunity cost for the shipper is also considered.
- Activity requirements according to load characteristics (ARL): transport system should be suitable for load characteristics.

- Activity requirements according to shipper needs $(A R N)$ : it is necessary to specify transport requirements, such as the expected minimum frequency among means of transport, according to the shipper needs. The kind of route covered by the transport system is another requirement that must be included in this group.

- Activity requirements according to the space-time context $(A R X)$ : these characteristics take into account the political and legislative framework. This framework often determines the transport operation and its development in the market.

The method finally defines the variables that are not controllable by shipping companies, which can be sorted as: static results (SR), belonging to the operational framework (port facilities and geographical feature among others), and dynamic results (DR), which can change with time due to temporary economic conditions and business strategy of competitors. Finally, the results, that are controllable by the company (CR), are technical and operational characteristics, that may vary depending on the design and operation of the transport system. From the analysis of these variables, it is also possible to identify the need objective functions and restrictions (from a qualitative point of view), which condition the success of a motorway of the sea. Due to the importance of the multimodal transport for peripheral countries, this paper proposes the evaluation of introducing a Short Sea Shipping (SSS) service with a motorway of the sea from Spain, using the hybrid model.

\section{THE EXPORT/IMPORT MARKET IN SPAIN: QUANTITAVE AND QUALITATIVE ANALYSIS}

First, it is important to evaluate the commercial flows to establish a possible transport route (ARN). Spain carried out in 2009 over a half of its commercial exchange within the EU. France and Germany are the main customers and suppliers, as shown in Table 1. In order to identify the possible users of a multimodal transport system, it is interesting to bear in mind that the European business net is built on small and medium-sized enterprises (SMEs), which constitute 20.8 million (private and non-financial) entities as compared with 43,000 large enterprises (according to the Annual Report on EU SMEs 2010/11, European Commission). 
Table 1: Distribution of the total volume of Spanish foreign trade from January to December 2009 (Ministry of Industry, 2009a)

\begin{tabular}{llll}
\hline & & $\begin{array}{l}\text { Export flows } \\
\text { to }(\%)\end{array}$ & $\begin{array}{l}\text { Import flows } \\
\text { from (\%) }\end{array}$ \\
\hline \multirow{3}{*}{ EU } & France & 19.34 & 11.71 \\
\cline { 2 - 4 } & Germany & 11.07 & 13.43 \\
\cline { 2 - 4 } & Italy & 8.17 & 7.24 \\
\cline { 2 - 4 } & Rest of UE & 12.10 & 10.64 \\
\cline { 2 - 4 } & Total UE & 69.11 & 58.01 \\
\hline Rest of Europe & & 6.40 & 6.23 \\
\hline North America & & 4.02 & 4.50 \\
\hline Latin America & & 4.74 & 4.68 \\
\hline Asia & & 7.03 & 17.74 \\
\hline Africa & 5.82 & 8.06 \\
\hline
\end{tabular}

Thus, the international commercial activity of SMEs is a great challenge for European economic policy. The Spanish SMEs represent the largest number of Spanish exporter companies $(67.9 \%$ in 2007), and export the largest volume of products (Tab. 2, Ministry of Industry, 2009b), exporting goods to the value of over 100,000 euros per year $(53.42 \%)$. Due to this, SMEs are the most interesting users of a transport service from Spain, and the most probable destination of the Spanish load is France.

Product features often determine the transport system selection (ARL). Thus, having identified SMEs as potential clients for a multimodal transport service, it is necessary to take into account the economic sectors to which their products belong.

Table 2 shows the distribution of products, grouped by economic sector. As can be seen in this table, SMEs exported $41.12 \%$ of the total exported volume in Spain in 2009, and their products belonged to the Spanish most important economic sectors. In addition, a multimodal system can transport any of their products.

Table 2: Spanish export trade by sector and producer company size

\begin{tabular}{cccc}
\hline \multirow{2}{*}{$\begin{array}{c}\text { Econom- } \\
\text { ic sectors }\end{array}$} & Products & $\begin{array}{c}\% \\
\text { total } \\
\text { Export } \\
\text { flow }\end{array}$ & $\begin{array}{c}\text { Produced } \\
\text { by export } \\
\text { Companies }\end{array}$ \\
\hline \multirow{4}{*}{$\begin{array}{c}\text { Equip- } \\
\text { ment goods }\end{array}$} & $\begin{array}{c}\text { agricul- } \\
\text { tural and in- } \\
\text { dustrial ma- } \\
\text { chinery }\end{array}$ & 1.26 & 69.70 \\
\cline { 2 - 4 } & $\begin{array}{c}\text { office } \\
\text { machines }\end{array}$ & 1.03 & 56.30 \\
\cline { 2 - 4 } & $\begin{array}{c}\text { other } \\
\text { transport ma- } \\
\text { terial }\end{array}$ & 1.09 & 60.70 \\
\hline
\end{tabular}

\begin{tabular}{|c|c|c|c|}
\hline \multirow{3}{*}{$\begin{array}{c}\text { Food } \\
\text { manufactur- } \\
\text { ing }\end{array}$} & $\begin{array}{l}\text { meat in- } \\
\text { dustry }\end{array}$ & 0.98 & 68.50 \\
\hline & $\begin{array}{c}\text { food } \\
\text { products and } \\
\text { tobacco } \\
\end{array}$ & 0.85 & 58.50 \\
\hline & drinks & 1.16 & 68.70 \\
\hline \multirow[t]{2}{*}{$\begin{array}{l}\text { Chemi- } \\
\text { cal manu- } \\
\text { facturing }\end{array}$} & $\begin{array}{l}\text { chemical } \\
\text { products (or- } \\
\text { ganic and } \\
\text { non-organic) }\end{array}$ & 1.35 & 55.60 \\
\hline & plastics & 1.23 & 77.80 \\
\hline \multirow{2}{*}{$\begin{array}{c}\text { Con- } \\
\text { sumption } \\
\text { manufactur- } \\
\text { ing }\end{array}$} & $\begin{array}{l}\text { textile in- } \\
\text { dustry }\end{array}$ & 0.94 & 79.50 \\
\hline & $\begin{array}{r}\text { leather } \\
\text { and shoes }\end{array}$ & 1.00 & 91.00 \\
\hline $\begin{array}{c}\text { Non- } \\
\text { perishable } \\
\text { goods }\end{array}$ & $\begin{array}{l}\text { furniture } \\
\text { industry }\end{array}$ & 0.87 & 76.80 \\
\hline \multicolumn{3}{|c|}{$\begin{array}{l}\text { Weight of studied sectors in the total } \\
\text { Spanish export flow in } 2009(\%)\end{array}$} & 62.30 \\
\hline \multicolumn{3}{|c|}{$\begin{array}{l}\text { Weight of SMEs' production in the to- } \\
\text { tal export flow in Spain } 2009(\%)\end{array}$} & 41.12 \\
\hline
\end{tabular}

\section{THE COMPANY: TRANSPORT SYSTEM ALTERNATIVES}

\subsection{Shipper characteristics}

Traditionally, SMEs with international activity used road transport to cover their logistical needs, because this system adjusted to their competitive model. The main SME transport requirements define the ARL decision group. Those are high frequency of sending and receiving goods, 'door-to-door' service and appropriate size of the transport system for small volumes of different kinds of loads. However, the trend towards association has been very remarkable in recent years (ARN). Because of this, the creation of clusters and consortiums of SMEs has appeared as a strategy to improve the transport conditions offered to them. Within this tendency, a multimodal maritime transport system arises as a real alternative to road transport for the transportation of small volumes with high frequency. In addition to the favourable effects of business association (ARN), it is important to note that the gregarious location of the SMEs also allows them to take advantage of logistic synergies and to centralize the transport demand (SMEs tend to establish themselves around industrial centres). Despite this, SMEs do not benefit from the effects of economy of scale, so they must minimize the cost attributable to the load. To this end, it is necessary to maximize the occupancy ratio in the transport system. 


\subsection{Opportunities for the multimodal system}

Road transport was the system used by more than $83 \%$ of the goods exchanged between Spain and France in 2008 (INE 2008). Due to this, the competitiveness between road transport and multimodal transport must be analysed (ARC), in order to determine its strong and weak points. This analysis evaluates two main features of transport operation (Mangan et al., 2001): the transport cost for users and their opportunity cost in terms of time (ARC).

The gap between the shipper sending its commodities and unloading them at their destination will be the total transit time. Therefore, this time is a critical parameter for every kind of sector and goods for SMEs. The average speed and transit continuity influence the time. The first point is limited for road but not for maritime transport. Despite congestion situations in road traffic, loss of time at the port and low fluid connections, between the different means of transportation, give road transport an advantage regarding transit continuity. In fact, time is a recognized weak point for the competitiveness of the multimodal system (Olivella et al. 2004, García-Ménendez \& Feo-Valero 2009). Nevertheless, EU regulation is balancing this point as we explain in Section 6.

The transport cost has a very important bearing on the total cost of every metric ton produced by SMEs as they transport small volumes. Despite the fact that maritime transport has turned out to be the most energy-efficient alternative (White Transport Paper 2001) for multimodal transport, it is necessary to add the goods transportation cost by land to maritime traffic costs. In order to balance the favourable situation of road transport regarding costs, the EU member states have applied a payment policy to road transport and tried to reduce the port costs for ships covering regular lines between European ports (Reform of the White Paper 2006). In addition to this, in many cases, the average distance travelled through multimodal transport is less than that travelled by road; hence, this point should be favourable to the multimodal system.

\section{ROUTE SELECTION}

This section carried out the port selection to establish a maritime route in an intermodal chain, considering the relative situation of intermodal transport regarding other competitors (ARC). The EMMA study concluded that the optimal maritime distances for using SSS are between 500 and $1400 \mathrm{~km}$ (ARN). Afterwards, in 1999, the Communication 'Development of the short sea shipping in Europe' established that the most interesting average distance for SSS (origindestination) was $1385 \mathrm{~km}$. In 2004, the INECEU Project concluded that from Spain the minimum maritime distance to achieve SSS effectiveness was $834 \mathrm{~km}$.

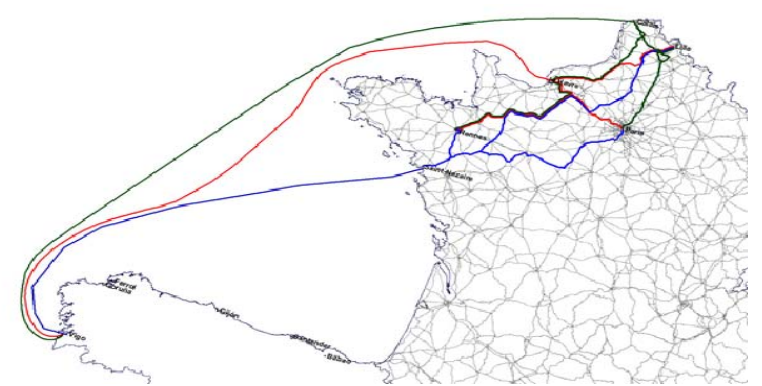

Figure 1: Multimodal routes from Vigo port to Lille, Paris and Rennes through the French ports of St. Nazaire, Le Havre and Calais

The results achieved in this project also showed that, as the studied ports are closer to the Pyrenees, road transport emerged as the best choice, especially regarding time. Nevertheless, in ports on the Spanish north coast, the farthest from the Pyrenees, the difference in time between the two transport systems (maritime and road system) was not too large. Finally, it is worth mentioning that the WEST-MoS Project (2008) concluded that the average distance through the Pyrenees was $1371 \mathrm{~km}$ (ARN), in order to ensure the competitiveness of multimodal transport. Taking into account all the previous points, the Spanish ports selected for the study were (ARC) Gijón, A Coruña and Vigo. These ports are ends of routes in Spain due to the features of their hinterlands (Garcia-Alonso \& Sánchez-Soriano 2010). On the other hand, the final destination of goods are French cities, according to the possible routes (Tab. 3), because the main population centres are also the main consumption centres for SMEs' products. However, you can only reach Paris, Lille and Rennes through the Atlantic coast. Therefore, the French ports selected are Calais, Le Havre and St. Nazaire, because they are the most suitable to reach the mentioned cities, and they move the highest volumes of general load on the French Atlantic coast. According to Table 3, and with the exception of Gijón-Rennes, road distances are about $1385 \mathrm{~km}$, which is the recommended distance for using SSS. Regarding the maritime routes recommendation $(834-1400 \mathrm{~km})$, Vigo is suitable for every possible French port; St. Nazaire does not meet this requirement in the case of A Coruña and Gijón (ARN).

Table 3: Distance of Atlantic routes between Spain and France $(\mathrm{km})$ 


\begin{tabular}{lllll}
\hline $\begin{array}{l}\text { Span- } \\
\text { ish } \\
\text { Ports }\end{array}$ & $\begin{array}{l}\text { French } \\
\text { Ports }\end{array}$ & Distance & $\begin{array}{l}\text { French } \\
\text { Cities }\end{array}$ & $\begin{array}{l}\text { Road } \\
\text { Distance }\end{array}$ \\
\hline Vigo & Calais & 1390 & Rennes & 1453 \\
\cline { 2 - 5 } & $\begin{array}{l}\text { St. } \\
\text { Nazaire }\end{array}$ & 915 & Paris & 1577 \\
\cline { 2 - 5 } & Le Havre & 1232 & Lille & 1793 \\
\hline A & Calais & 1225 & Rennes & 1392 \\
\cline { 2 - 5 } Coruña & St. & 735 & Paris & 1514 \\
& Nazaire & & & \\
\cline { 2 - 5 } & Le Havre & 1067 & Lille & 1731 \\
\hline Gijón & Calais & 1138 & Rennes & 1061 \\
\cline { 2 - 5 } & St. & 563 & Paris & 1184 \\
& Nazaire & & & \\
\cline { 2 - 5 } & Le Havre & 980 & Lille & 1400 \\
\hline
\end{tabular}

Accordingly, the previous results, based on distance, are not sufficient to make a decision about the best maritime route with which to establish a multimodal transport system. It is necessary to carry out a new evaluation in terms of competitiveness (ARC). The comparison of the multimodal chain (stretch by land and by sea), with regard to road system, were carried out in relation to time and cost. To this end, speeds of 80 $\mathrm{km} / \mathrm{h}$ on regular roads and $90 \mathrm{~km} / \mathrm{h}$ on motorways (ED 92/24/CE, 92/6/CE) were considered in the case of road transport. Additionally, this works evaluated two operational possibilities: a maximum of 9 hours per driving day and continuous driving, with different drivers observing the compulsory breaks. For maritime voyages, a speed of $30 \mathrm{kn}$ for ferries of 157 trucks and a load/unload speed of 34 trucks/hour (Authority of Vigo Port) were taken. The vessel speed could be considered too bold; however, the WESTMoS Project estimated an effective speed of 28 $\mathrm{kn}$ for ships covering the minimum frequency required for SSS to be economically sustainable. The INECEU Project kept the same idea, and even other studies presented high-speed crafts as an option for this kind of traffic (SPIN-HSV Study 2004).

Neither the difference in cost savings nor the difference in time increases was wide enough to select a Spanish port as the optimal departure port (ARCs are not deciding factors). Hence, it is necessary to apply another criterion: the nature of the goods (ARL). Therefore, this work considers loaded and unloaded goods in Spanish ports and their potential market. Despite the fact that other studies about ports competitiveness have used different decision makers (GarcíaAlonso \& Sánchez-Soriano 2010), in our hybrid model, the load producer was assumed as the unique decision maker.

Table 4: Volume of general goods and containers, exported and imported in 2009 (tons)

\begin{tabular}{lll}
\hline & Total & Container \\
\hline Coruña & 1444840 & 123724 \\
\hline Gijón & 587401 & 175016 \\
\hline Vigo & 2607037 & 1582047 \\
\hline
\end{tabular}

Table 4 shows Vigo as the port with the largest exchange of general goods. It also moves the largest quantity of goods in containers (a necessary characteristic of SMEs' load). Consequently, the port selected as the Spanish reference port was Vigo. Due to maritime transport is a part of intermodal transport, the influence of loading/unloading operations in port are included, in order to ascertain the advantages of using port facilities (ARL). Many previous studies concluded that, in terms of time, the use of port facilities for containers is more efficient in Europe (González \& Trujillo 2008) than using the vessel's facilities. However, the influence of technical advances in this field was not as important as expected in Spanish ports and the average efficiency was 91.9\% (González \& Trujillo 2008). Analysing the port hinterlands of the selected French ports, the following characteristics are remarkable:

St. Nazaire is the nearest port to the Rennes area. The distance Nantes-Paris is greater than the distance from the port of Le Havre but St. Nazaire is a good option for the intermodal chain as the total time invested is shorter.

Le Havre port establishes a very important route from Vigo due to its great proximity to Paris. This maritime route also reaches Lille.

Calais is an interesting port for import and export flows with Belgium and United Kingdom from Spain. In addition, the French hinterland of Calais port spreads out to Lille, or even to Paris.

Within a radius of $300 \mathrm{~km}$ (ARN) around Vigo, there are more than $220 \mathrm{SME}$ centres in Spain and in the north of Portugal, down to Porto. Therefore, there is a load potential of Vigo port hinterland towards France.

\section{FLEET SELECTION}

According to the potential market detected (SMEs), the current situation of the studied ports and load nature, containers or trailers (ARL) are suitable. This is due to the necessity of moving small volumes of very different goods. The kinds of load, vessel and facilities used are mainly responsible for loading and unloading operations costs (ARL). For the case of SSS, the shipping company assumes these costs and they are included in the freight cargo. 'Rules for the Motorway of the sea between Spain and France' (BOE No 265 2006) were consulted to determine the minimum cargo needs for vessels. The re- 
quirement was a minimum amount of cargo units (containers or trucks) of 221 per day and direction independently of the kind of vessel used. Additionally, as seen before, it is necessary to maintain a minimum vessel speed of $30 \mathrm{kn}$ to ensure the competitiveness of multimodal transport. It is also important to avoid the highspeed craft condition, as it introduces many operative restrictions (SPIN-HSV Study 2004). Both requirements apply to vessels of a minimum length of $100 \mathrm{~m}$. Vessels of $150 \mathrm{~m}$ in length operating at $35 \mathrm{kn}$ would not reach the condition of high-speed craft (MSC 36(63), SOLAS, Chap. X); therefore, these two alternatives will be studied. All the studied ports have available infrastructures to offer a cargo handling service for a ro-ro cargo (ARL), and enough equipment for load operations of containerized goods, with the exception of Calais. The load speed considered for the operation with ship cranes ( 2 per vessel of $100 \mathrm{~m}$ in length and 3 for $150 \mathrm{~m}$ in length) is as follows:

Rate per ship crane $=13$ containers $/ h$

The alternative of using port cargo handling equipment means initial savings in shipbuilding cost, compared with another alternative, but, as a disadvantage, this option implies large dependence on ports' facilities (ARN) and efficiency (ARL). The load speed for port cranes was:

Rate per port crane $=27$ containers $/ h$

The following equation applies to the time invested in cargo operation for trucks without a tractor unit (Ametller 2007):

Rate $=8$ trucks $/ h \cdot$ driver

The time invested in the trucks load with a tractor unit, using port drivers is expressed (State Stowage Society of Vigo Port) as:

$$
\text { Drivers }=\text { trucks } / 45
$$

For both kinds of cargo units, the fastest mode is to use port facilities. Therefore, this work considers these options for calculating the possible fleets. On the other hand, the kind of ship mainly determines the ship costs (ARL). They consist of port dues, port services and costs of the representation agency of the shipping company in port. According to load nature (ARL), the following ship types are suitable for containerized or rolling goods: roll-on roll-off ship (RO-RO), mixed ship: RO-RO and container (CONRO) and container ship. In order to meet the previous requirements, it is necessary a RO-RO fleet of two vessels (in each direction) of $150 \mathrm{~m}$ in length (153 trucks), operating at $35 \mathrm{kn}$, or 3 vessels of $100 \mathrm{~m}$ in length (85 trailers) at $30 \mathrm{kn}$.

CON-RO ships make better use of the available space in the cargo hold. The possible fleets (in both directions considering cargo port facilities) are two vessels of $100 \mathrm{~m}$ in length (42 trailers and 133 TEUs); due to time restriction, the total time invested in the maritime stretch is higher than $24 \mathrm{~h}$ considering the port facilities. Alternatively, two vessels of $150 \mathrm{~m}$ in length (59 trailers and 716 TEUs) due to the cargo restriction.

The container ship optimizes the unitary space for the load (ARC) and its structure is the least complicated; therefore, the initial investment in the ship is lower. In this case, the fleet would consist of two vessels of $100 \mathrm{~m}$ in length (237 TEUs) or two vessels of $150 \mathrm{~m}$ in length (1200 TEUs).

\section{TRANSPORT REGULATIONS}

Regulations apply to this sector strongly determine the transport system selection. Therefore, the decision group of activity requirements, according to space-time context (ARX), will exert a large influence on the opportunities for ship owners and shippers. From the policy trend analysis, we can conclude that the EU protectionism over maritime transport has lightened over the years. Firstly, the Code of Conduct on Maritime Conferences established the distribution of cargo tons proportionally between conference members. Afterwards, Regulation 4056/86 allowed a system of exceptions by categories, establishing the access to maritime traffic competition. Finally, Regulation 1/2003 abolished all the exceptions, excluding 'tramp traffic' and coastal navigation. The main consequence of the sector deregulation is the increase in competitiveness among shipping companies, and therefore the service price decrease, which benefits the multimodal transport system's competitiveness.

With the purpose of freeing European roads from the large amount of traffic, the EU has decided to boost SSS as a serious alternative to the road transport system (since the publication of the first White Paper in 1992). Among the main drawbacks detected for the development of SSS were the administrative complexity and customs formalities. These were resolved through Directive 2002/6/CE (which established the use of FAL Convention work forms in all member countries). With the purpose of improving port efficiency, the EU has encouraged private initiatives in port services. The main lines address towards deregulating the stowage business, in order to encourage competition.

In 2006, EU published a study on motorways of the sea opportunities, carried out by the Coordination Platform for Maritime Transport (Atlantic Transnational Network 2006) within the VI Framework Programme. This study stated that there was a great projection between the central French coast and ports of the north of Spain, 
both for RO-RO traffic and for container traffic. This conclusion reinforced the previous objective of developing the Western European motorway of the sea before 2020 (included in the N21 Project 2009), which would connect Spain and Portugal with the Irish Sea and the North Sea through France (ARN). Consequently, France and Spain signed, in October 2005, a collaboration agreement ('Declaration of Intentions about Motorways of the sea'), for selecting proposed projects on motorway of the sea between the two countries. Notwithstanding the public financing for these projects, the requirements for liner services are quite demanding. In fact, this agreement demands a minimum movement of 350,000 semitrailers (ARL) in the first 5 years between the two affected countries, and a minimum frequency of 4 voyages in each direction per week, during the first 2 years (221 cargo units moved in each direction). This boosted a favourable rule atmosphere for shipping companies (ARC) that operate between Spain and France.

\section{CONCLUSSION}

From an academic perspective, the paper contributes to the multimodal transport literature by proposing a method that addresses the opportunity assessment of a motorway of the sea, integrated into a multimodal chain, in order to adapt the shipping company service for the real shipper needs. The proposed methodology applied a set of scopes, in accordance with a hybrid model, built on conclusions extracted from different decision groups based on shipper's criteria. This work sorted the results according to the possibilities of the company to act on them, and those that determine the strategy suitability to the circumstances and market tendency. The following paragraphs show all of them.

No controllable results: Static results (SR):

The transit time in the intermodal system is a disadvantage for multimodal transport. The $\mathrm{Eu}-$ ropean transport policy is trying to minimize this problem through the standardization of customs formalities for maritime transport, and the introduction of deregulated load and unload services among others.

The most important characteristics of a transportation service for SMEs are small and medium volumes of load with a high frequency of sending in a 'door-to-door' service.

EU is still committed to private enterprise as responsible for establishing and operating competitive motorways of the sea. This requires ship owners to enhance the optimization of their resources and rethink their competitive position in the market.
Transport attributes that clearly determine the modal decision are time and cost, the difference maximization from the main competitor in transport is the goal to pursue.

The Spanish ports, selected to operate with French ports, in terms of operational versatility and recommended distances, were A Coruña, Gijón and Vigo.

Vigo port, as the extreme of the routes studied, would allow SMEs to operate in a radius of 300 $\mathrm{km}$ (Spain and Portugal) with multimodal transport, with the same time and cost as road transport.

Calais port poses an operative constraint due to its lack of cargo handling system for containers.

All the studied ports have the infrastructure required to provide a motorway of the sea (berths of $200 \mathrm{~m}$ and loading ramps for RO-RO). Given the characteristics of these ports, the ship size that would maximize the operational flexibility would be $100 \mathrm{~m}$ in length and depth not exceeding $7 \mathrm{~m}$. With these dimensions, the ship can expect to avoid waiting times at port.

No controllable results: Dynamic results (DR):

The trend towards globalization and the shortened life cycles of products require SMEs to establish international activity. SMEs' size and importance is growing in Spanish foreign markets. This identifies SMEs as a target charger for multimodal transport.

The main customer and sending country for Spanish foreign freight is France.

Once the transport system is suitable for SMEs, costs and time become critical factors to assure the transport system's competitiveness. Consortiums among shippers lead to better cargo space use and good unitary cost minimization.

The French cities selected as route ends were those with the most populated metropolitan areas, and the selected French ports were those whose geographical position and importance in the French port system were relevant (Fig. 1).

Finally, Vigo port was selected as the Spanish port in this research (Fig. 1), due to having the largest quantity of container freight movement; therefore, it presented the best prospects for attracting container cargo, in spite of the fact that it was not the best placed in terms of time.

Controllable results (CR):

The vessels' adaptation to port demands and to the routes at a high operation's speed (without reaching the category of 'high-speed craft') could resolve the intermodal system delay time versus road transport.

To meet the motorway of the sea requirements between Spain and France, it will be necessary to provide at least three container ships of $100 \mathrm{~m}$ in length. If larger ships are used to this end, these will be able to operate at a higher speed (without 
considering them as 'high-speed craft'). The use of smaller ships implies a reduction in their operational speed and, therefore, their competitiveness; for this reason, we ruled out this option. Therefore, the vessel speed and the number of ships will be other controllable variables to define.

The studied routes (Fig. 1) were the shortest in distance, articulating each chain a 'one-to-one' model. Although all of them complied with the recommended distances in previous studies, this distance was the most important selection parameter, and it would be necessary to choose the maritime route taking into consideration burden distribution between different destinations in France ('one-to-many' or 'many-to-many' models). Therefore, the selection of a single route between two ports will be an important variable to set.

The multimodal chain's competitiveness in terms of cost links to the port charges, which depend primarily on the vessels' features (auxiliary variables: length between perpendiculars, tonnage, etc.). These features depends on the type of vessel, type and amount of cargo units, manoeuvring means and selected cargo handling systems. Vessels suitable for cargo transport were containers, RO-ROs and CON-ROS.

Based on the uncontrollable results (SR and DR), it is appropriate to accept that the establishment of a motorway of the sea between Spain and France is a favourable opportunity, as it adapts to the environment needs and studied context tendency. Despite this fact, it will be necessary to take decisions about the fleet, the route and the client, in order to optimize this opportunity. For this reason, this work qualitatively defines some objective functions, key variables that influence the achievement of these objectives, their relationships and their constraints. These decisions directly influence the acceptability of the business strategy and therefore different cases and alternatives should be analysed in a further study.

\section{REFERENCES}

Ametller 2007. Optimización del transporte de mercancías mediante tráfico marítimo de corta distancia. [Optimization of the Load Transport through Short Sea Shipping]. Thesis, Department of Transport Engineering, Polytechnic University of Cataluña.

Atlantic Transnational Network, Work Group 'Accessibility' 2006. The Intermodality on the Load Transport: Ports and Hinterland, Maritime Transport Integrated in the Short Sea Shipping.

BOE No. 265 2006. Boletín oficial del estado español. Bases reguladoras de las Autopistas del mar entre España y Francia. [Rules for Motorways of the Sea between Spain and France].
COM (2004) 675. Commission of the European Communities 2004. White Paper about Review of Regulation (CEE) no. 4056/86 for that it Applies the Competitiveness Rules to Maritime Transports.

Council Regulation (EC) No. 1419/2006 of 25 September 2006 repealing Regulation (EEC) No. 4056/86 laying down detailed rules for the application of Articles 85 and 86 to maritime transport, and amending Regulation (EC) No.1/2003 as regards the extension of its scope to include coastal shipping and international tramp services. Official Journal of the European Union.

Directive 2002/6/EC (2002) of the European Parliament and the Council of 18 February 2002 on reporting formalities for ships arriving in and/or departing from ports of the member states of the Community. Official Journal of the European Communities (9.3.2002).

García-Alonso L. \& Sánchez-Soriano J. 2010. Analysis of the evolution of the inland traffic distribution and provincial hinterland share of the Spanish port system. Transport Reviews, 30 (3): 275-297.

Garcia-Menendez \& Feo-Valero 2009. European common transport policy and short-sea shipping: empirical evidence based on modal choice models. Transport Reviews, 29 (2): 239-259.

Gese \& Baird 2010. Motorways of sea policy in Europe. IAME Conference 2010. Lisbon

González \& Trujillo 2008. Reforms and infrastructure efficiency in Spain's container ports. Transportation Research Part A, 42:243-257.

IMO 1994. International Convention for the Safety Of Life At Sea (SOLAS). Chapter X: Safety measures for high speed craft. Resolution MSC 36(63).

INE (Instituto Nacional de Estadística) [National Statistics Institute] 2008. Ministry of Economics. Spanish Government.

Mangan, Lalwani \& Gardner 2001. Identifying relevant variables and modeling the choice process in freight transportation. International Journal of Maritime Economics, 3 (3): 278-297.

Ministry of Industry 2008. Informe mensual de comercio exterior. [Monthly Report of Foreign Trade]. Spanish Government.

Ministry of Industry 2009a. Informe mensual de comercio exterior. [Monthly Report of Foreign Trade]. Spanish Government

Ministry of Industry 2009b. Informe sobre la PYME 2009. [Report about the SMEs]. Goverment of Spain.

Olivella Puig, Martínez de Osés \& Castells Sanabra, M. 2004. Intermodalidad entre España y Europa, el proyecto INECEU. [Intermodality between Spain and Europe]. Research group TRANSMAR, Polytechnic University of Cataluña.

Sapag, N. 2001. Evaluación de proyectos de Inversión en la empresa. [Assessment of Investment Projects in Business]. Prentice Hall, Madrid.

SEPI Fundation 2009. Las empresas industriales en 2008. [The Industrial Business in 2008]. Encuesta Sobre Estrategias Empresariales (ESEE).

SPIN-HSV Study 2004. Shipping Quality and Safety of High Speed Vessels, Terminals and Ports Operations in Nodal Points. V Framework Programme of the European Commission

Trans-European Transport Network Executive Agency 2009. Project N21: Motorway of the Sea.

WEST-MoS Project: Western Europe Sea Transport \& Motorways of the Sea Project (2005-2008). Co-financed by the European Union from the Trans-European Networks (TEN). 